\title{
The Symbol and the Theory of the Life-World: "The Transcendences of the Life-World and Their Overcoming by Signs and Symbols"
}

\author{
JOCHEN DREHER \\ Department of Sociology, University of Konstanz, Konstanz, Germany
}

\begin{abstract}
This essay presents a phenomenological analysis of the functioning of symbols as elements of the life-world with the purpose of demonstrating the interrelationship of individual and society. On the basis of Alfred Schutz's theory of the life-world, signs and symbols are viewed as mechanisms by means of which the individual can overcome the transcendences posed by time, space, the world of the Other, and multiple realities which confront him or her. Accordingly, the individual's life-world divides itself into the dimensions of time, space, the social world and various reality spheres which form the boundaries or transcendences that the I has to understand and integrate. Signs and symbols are described as appresentational modes which stand for experiences originating in the different spheres of the life-world within the world of everyday life, within which they can be communicated, thereby establishing intersubjectivity. Schutz's theory of the symbol explains how social entities - such as nations, states or religious groups - are symbolically integrated to become components of the individual's life-world. The following paper reconstructs Schutz's concept of the symbol as a crucial component of his theory of the life-world, which is seen as an outstanding phenomenological contribution to the theory of the sign and the symbol in general.
\end{abstract}

Key words: phenomenology, Schutz, Husserl, Cassirer, Jaspers, Luckmann, life-world, symbol, sign, intersubjectivity, communication

\section{Introduction}

Phenomenological investigations into the theory of the symbol as a life-world phenomenon are rare and rather exceptional. This essay views the concept of the life-world from a subjectivist perspective to understand the interconnection of individual and society, which is established - as we will show - by means of the mechanisms of signs and symbols. The individual experiences the transcendences of the life-world - of space, time, sociality and different spheres of reality - and is able to overcome these transcendences by means of signs and symbols. The following systematic analysis reconstructs Alfred Schutz's concept of the symbol, the central component of his theory of the life-world, in order to open a phenomenological perspective on how symbols function in the interrelation of individual and society. 
Schutz's basic concern was to establish a philosophical foundation for social scientific inquiry; his investigations were centered in particular on a renewal of Max Weber's Interpretative Sociology. This project was influenced to a large extent by his discovery of the phenomenology of Edmund Husserl, a paradigm that suited his research intentions. The merit of Schutz' work can be seen in the phenomenological foundation he gives the social sciences, in his development of a methodology of Interpretative Sociology, as well as in his theory of action and in his theory of the life-world.

In contrast to these themes within Schutz's work, his concept of the symbol has hardly received recognition, although the importance of this topic should be emphasized, especially for his theory of the life-world - a perspective which forms the basis of my argument in this paper. In his later investigations the concept of the symbol was of crucial importance until the completion of the Structures of the Life-World by his student Thomas Luckmann. ${ }^{1}$ His outline for this planned oeuvre proves that he intended to establish a theory of the symbol as an essential component of his theory of the life-world (cf. Schutz, 1989a, p. 159ff.). He demonstrates how experiences of multiple realities constituting the individual's life-world are connected to the paramount reality of everyday life through symbolization to be communicated within the intersubjective life-world.

Schutz's second, late concept of the symbol emerged in his essay "Symbol, Reality and Society"2 of 1955, only a few years before his death. This can be regarded as a continuation of his well known 1945 essay "On Multiple Realities." 3 The culmination of the development of his "late concept of the symbol" was planned for his last systematic work, The Structures of the LifeWorld, in which symbols as well as marks, indications, and signs are defined as a means for the overcoming of the transcendences of the life-world. Precisely these plans will be the basis of the argumentation of this essay.

It was Thomas Luckmann's difficult task to complete a "summary of Schutz's life's work," which Luckmann accomplished on the basis of Schutz's manuscripts to be found in the "Notebooks." Significantly, Luckmann's elaboration of Chapter VI of Vol. 2 of the Structures of the Life-World differs from the original manuscript and a planned Chapter V about "signs and symbols;" this difference can be clearly proven by a comparison with Schutz's project outline for his work (Schutz, 1989, p. 174ff; Schutz and Luckmann, 1989, p. 99ff). In order to describe Schutz's "late concept of the symbol," this essay concentrates on his manuscripts in the "Notebooks" which contain his attempt to work out a theory of the symbol as well as one of communication. Schutz intended to mark his outline of the relevant "symbol chapter" with the title "The Transcendences of the Life-World and Their Overcoming by Signs and Symbols." 5

The concentration on Schutz's late "Notebooks" makes it possible to specify Schutz's theory of the symbol as part of his theory of the life-world which 
has been almost neglected by the reception of his work to date. ${ }^{6}$ I argue that Schutz's concept of the symbol is crucially integrative to the constitution of the life-world as an intersubjective entity with its multiple spheres of reality. Symbols as part of our social stock of knowledge enable us to indirectly communicate experiences of everyday transcendent realities - like religion, science, politics, etc. - within the reality of everyday life; through symbols the multiple realities are represented within the reality of everyday life and through communication these realities can become intersubjective and objectified and therefore can influence human action. The crucial point of the analysis describes systems of symbols both as integrative in the cohesion of the subjectively experienced intersubjective life-world and as representing everyday transcendent realities, and what is more: they are also integrative for the order of society. It is the intention of this essay to explore these interconnections.

\section{Signs and Symbols as Means to Overcome the Trancendences of the Life-World}

With a focus on phenomenological analysis of the symbol and in order to clarify Schutz's "late concept of the symbol," we must understand his basic concept of the life-world. First of all, Schutz defines the "world of daily life" as the reality experienced within the natural attitude by the alert adult who acts within it and upon it amidst his or her fellow human beings. The "natural attitude" is the state of consciousness in which we accept the "reality of everyday life" as a given. Because it is governed by a "pragmatic motive," the everyday life-world is something that we have to modify by our actions or that modifies our actions (Schutz, 1962, pp. 208-209). The everyday life-world includes both the cultural meaning-stratum that first makes physical objects into objects of naïve experience as well as the everyday social world. Furthermore, the life-world, in Schutz's use of the term, embraces still more than the everyday reality. We regularly sink into sleep and relinquish the natural attitude in order to lapse into fictive worlds and fantasies. Furthermore we are able to transcend everydayness by the means of symbols and, as a special case, are able consciously to modify our natural attitude and shift to different reality spheres. Schutz grasps the idea of the life-world so broadly that it includes all modifications of attitude and alertness, in other words, every tension within consciousness present in the normal adult (Schutz and Luckmann, 1974, p. 21).

The life-world must necessarily be seen as a pre-theoretical world of experience; life-world describes a certain stratum of human experience previous to the socio-historical world with its essential invariant structures that exist within all human acts of consciousness (Luckmann, 1983, p. 41). Husserl, from whom Schutz adopts a modified version of the concept of the life-world, dis- 
covers a general structure belonging to the life-world in all its relativities wherein all relative Being is tied to this general structure which itself is not relative (Husserl, 1954, p. 141).

\section{Signs and Symbols as Elements of the Life-World}

Within Schutz's conception, the fundamental problem faced by human beings is to attain an orientation on the basis of their position within a cosmos that transcends the existence of the former. On one hand, the "working individual" constitutes a life-world as a "conditio humana," and, on the other, the individual is located within the ordered realities of objective systems of meaning within the social structure of everyday life. According to Schutz, sign and symbol are among the means by which we try to come to terms with the manifold experiences of transcendence. He tries to show how the perceptible world factually available to the individual at any given moment presents open horizons of space and time that transcend his actual Here and Now. Secondly, he demonstrates how a common communicative environment originates in the understanding of the fellow human beings and how the Other's existence and that of society transcends in still another sense the individual's actual experiences. $^{7}$

Schutz intends to demonstrate that a specific form of what Husserl called "appresentations" - he designates them as marks, i.e., marking signs, indications, signs - corresponds to each of these particular transcendences. The one thing these transcendences have in common is that they are experienced within the reality of everyday life. This reality, which William James calls "paramount reality," is not the only reality in which the individual human being lives. But there are other transcendences beyond those mentioned so far - James' theory describes different multiple realities or "subuniverses," such as the worlds of religion, art, and science (cf. James, 1950, Ch. XXI), that can only be experienced in the unique form of appresentation for which Schutz reserves the term "symbol."

"The world of everyday life, of everyday experience, has a paramount position above other provinces of reality, since only within it does communication with our fellowmen become possible" (Schutz, 1989a, p. 244). The world of everyday life is exclusively and fundamentally a socio-cultural world, the intersubjectivity of symbol-relations originates in it, and is also determined by it. For the early paragraphs of his "symbol chapter," Schutz already plans to define the human being as animal symbolicum in the terminology of Ernst Cassirer (1972, pp. 25-26). According to this definition, symbolization starts with human thought; the world experienced by human cognition is already pre-formed and a construction of consciousness - symbolic forms like language, religion, art, and science are products of the human mind. 


\section{Husserl's Concept of Appresentation}

The central mechanism within Schutz's concept of the symbol is the activity of consciousness called appresentation developed on the basis of Husserl's phenomenology. Husserl uses the term "appresentation" within his theory of intersubjectivity in Cartesianische Meditationen with the intention of describing the "making co-present" of the Other as part of the experience of the Other (Fremderfahrung) (Husserl, 1987, p. 50ff.). In particular, he focuses on the phenomenon of pairing or coupling, which he regards as a general feature of consciousness. Pairing is a form of passive synthesis which is commonly called association. ${ }^{8}$

At this point, Schutz's procedure differs from Husserl's in that it concentrates on the one particular form of pairing or coupling which Husserl calls "appresentation" or "analogical association," so that within his theory of the symbol the pairing of sign and signified receives special emphasis. The most primitive form of pairing or coupling association occurs when two or more data are intuitively given in the unity of consciousness, which, for this very reason, constitutes two distinct phenomena as a unity, regardless of whether or not attention is paid to them. The perception of an object in the outer world requires more than visually perceiving only the front side of the object. The case is an analogous apperception of the unseen other side, an apperception that is more or less empty. This kind of anticipation is based on our past experiences of normal objects of this kind (Schutz, 1962, pp. 294-295, 1989a, p. 244).

These remarks are now relevant to an understanding of the concept of "appresentation," which can be seen as apperception on a higher level. When appresentating we intuitively experience something as significantly indicating or depicting something else. Furthermore, experience by appresentation has its particular style of confirmation: each appresentation conveys its particular appresented horizons, which refer to further fulfilling and confirming experiences, to systems of well-ordered indications, including new potentially confirmable syntheses and new non-intuitive anticipations (Schutz, 1962, p. 296). Remarkably, Schutz states with reference to Husserl's concept of the "passive synthesis" in Erfahrung und Urteil ("Experience and Judgment," Husserl, 1985, pp. 34-43), that pairing is also possible between an actual perception and a recollection, a perception and a phantasm (fictum) and thus between actual and potential experiences, between apprehension of facts and possibilities.

The concept of appresentation becomes the central mechanism within the Schutzian concept of the symbol. It is based on Husserl's considerations, but used more widely and extensively for the description of the pairing of elements - one of the two elements being transcendent - on different levels of the spheres of the life-world. ${ }^{9}$ 
The basic Schutzian consideration concerning his theory of the life-world is the stratification of the life-world into different dimensions. Schutz defines a space, time, and social structure of the life-world; furthermore, he divides the life-world into multiple realities, into reality spheres of finite meaning structure; the individual is constantly confronted with given boundaries through the stratification of the life-world. As we will discover, marks, indications, signs, and symbols are the means which enable the subject to overcome - to transcend - these boundaries or transcendences. The solitary I has to overcome its transcendences established by space and time with marks and indications - Luckmann in his completion of the Structures of the Life-World calls them "little transcendences." The world of the Other transcends the world of the solitary I; the subject is confronted by "medium" transcendences given by the social world and is able to conquer this intersubjective life-world, as Schutz contends, with signs. Moreover, the individual is able to represent other realities in experiencing the "great" transcendences posed by other realities by the means of symbols. The stratification of the life-world is not the outcome of a genetic process; the three dimensions of the life-world cannot be described as evolutionary hierarchy: they are ideal-typical constructs for a systematic phenomenological analysis. The focus of this analysis will be on the "medium" and "great" transcendences with a special emphasis on the functioning of symbols.

If we consider first the solitary I's life-world, the individual uses marks as "subjective reminders" and "mnemonic devices" - like pencil strokes in a book which mark an important passage - to recognize specific objects again after a certain time. Marks are forms of appresentation that enable the solitary I to overcome the transcendence of his or her life-world established through time. On the other hand, the solitary I is able to understand his or her world within and beyond actual reach through indications, such as "natural signs" like the halo around the moon that indicates coming rain or the smoke I perceive in the distance that indicates fire. Indications enable human beings to transcend the unquestionably given opaque interrelations of the life-world; thus, the knowledge of indications is decisive for the individual to transcend the world within his actual reach, to overcome the spacial transcendences of the lifeworld (Schutz, 1989a, pp. 249-251).

\section{The Intersubjective Life-World}

Schutz develops the social dimension of the life-world by analyzing the world of everyday life as an intersubjective one from the outset. He argues that marks and indications do not necessarily presuppose the existence of fellow human 
beings and communication, for they can be explained by the "pragmatic motive" that determines the individual in coming to terms with the world within his reach. But the life-world is by no means a private world; I share it with my fellow human beings and so it is intersubjective from the outset. It is also experienced and interpreted by others and it is a world common to all of us. I find myself continually located in a historically given world which, as the natural world and the social world (cultural world), has existed before my birth and will continue to exist after my death. We take for granted the bodily existence of fellow human beings with consciousness, as well as that the possibility of communicating with them exists.

According to Husserl, the basis for intersubjectivity is the "face-to-facerelationship"; he presupposes as self-evident that the appresentational comprehension of events in the other's minds leads immediately to communication. Following this analysis, Schutz develops his well-known general thesis of the "reciprocity of the perspectives," which is centered upon the two idealizations of the "interchangeability of standpoints" and the "congruence of the systems of relevancy" (Schutz, 1962, pp. 315-316). These establish the basis for the overcoming of the transcendences of the intersubjective life-world.

$\mathrm{Up}$ to this point of the analysis, the face-to-face-relationship, in which a sector of the world lies within both mine and the Other's actual reach, has been the focus of interest; there is an intersection between my world within reach and the other's world within reach. But there are necessarily zones within my reach that do not lie within the other's reach, and vice versa also in reference to our manipulatory spheres. In this sense, the other's world transcends mine. According to this consideration, Schutz develops a three-stage stratification of the transcendences of the intersubjective life-world, the social world (Schutz, 1989a, pp. 255-257), ${ }^{10}$ which is of special interest from a sociological perspective:

\section{First Transcendence - The Other's World Within Reach Transcends Mine}

The presumption that the world within the other's actual reach lies within my potential reach, and vice versa, is a corollary of the idealization of the interchangeability of standpoints.

\section{Second Transcendence - Transcendence of the Other's Existence Itself in the Pure We-Relationship}

Only in the face-to-face-relationship are the bodies within reciprocal reach, only in it do we experience each other in our individual uniqueness and are we mutually involved in one another's biography. ${ }^{11}$ The crucial consideration at this point also is that the existence of the other transcends my existence, and vice versa. We only have a small section of our biographies in common and, moreover, each of us enters the relationship, according to Simmel, with only a small part of his or her personality - in other words, by assuming a 
particular social role. Furthermore, the other's system of relevance is founded in his or her unique biographical situation, and thus cannot be congruent with mine; it cannot be brought within my reach, although it can be understood by me. The overcoming of this second transcendence of the other's world makes it possible to explain how phenomena like "friendship" or "love" as social relationships are symbolized within the face-to-face-relationship.

Third Transcendence - The We-Relation as Such Transcends My and Your Existence

This transcendence surpasses not only my world, but also the other's world. Although constituted in their mutual biographical involvement, it transcends the existence of either of the consociates within the reality of daily life. It belongs to a finite province of meaning other than that of the everyday world, and can be grasped only with the help of "symbols," as Schutz argues. He demonstrates that the "we-relation as such," like "nations" or "religious groups," even though defined by the transcendences of the other's world, is appresented through symbols that are part of a different province of meaning, possibly because the collective appresented by the symbol within the "everyday life-world" is a common-sense thought construct. ${ }^{12}$ This point will be consolidated later through the description of symbolical appresentation.

\section{Signs, Communication and Language}

Schutz could prove that the life-world is intersubjective from the outset. His theory of the "experience of the other," as we have shown, is the basis for the stratification of the other's world. The overcoming of the transcendences of the intersubjective life-world through signs as forms of appresentation and the phenomenon of communication are crucial within his sign theory as part of the theory of the life-world; the we-relation is the foundation for communication and also for the communicative life-world. ${ }^{13}$ Every understanding of another's thought (disregarding telepathy) requires an object, fact, or event in the outer world, which is not apprehended as such, but as a so-called "expression" of the cogitations of a fellowman. These cogitations include in the Cartesian sense feelings, volitions, and emotions, whereas signs are those objects, facts, or events in the outer world; e.g., spoken or written words, whose apprehension appresents the cogitations of the other to an interpreter (Schutz, 1989a, p. 257). They are interpreted signs of another's mind, and must be referred directly or indirectly to the existence of the other's body.

For communication as such, it is of no importance whether the world within the interpreter's reach spatially overlaps the manipulatory sphere of the communicator (telephone, television), nor that the production of the sign occurs simultaneously with its interpretation (writing, monuments), nor finally that 
the same object, fact, or event chosen by the communicator as carrier and vehicle of communication be perceived by the interpreter (Schutz, 1989a, pp. 259-260). The decisive factor in communication is that it requires, under all conditions, events or objects in the outer world produced by the communicator and, furthermore, events or objects in the outer world perceptible by the interpreter. Communication can only occur within the reality of the outer world, within the reality of everyday life. This is one of the dominating reasons that it has the character of a privileged or "paramount" reality.

For a successful communicative process, mutual abstractions and standardizations are necessary which are based on the idealization of the congruence of systems of relevance. Thus, interactions require objectification in a mutual, communicative life-world (Knoblauch, 1995, p. 58). Communication can only be successful if the action of the individuals is coordinated by objectifications sharing a common meaning, and if all acting persons assume the mutuality of this meaning as working-communicating individuals. Meaning is not produced by the subjective consciousness. This indicates that mutually valid signs are on the one hand produced by "appresentation" as a mechanism of consciousness, which is always responsible for the creation of signs; on the other hand, they are produced within related actions oriented towards the pragmatic motive.

Language as a sign-system can, without any doubt, be characterized as one of the most significant systems of appresentation. Not only does it carry the appresentative function of reference of sounds with certain meanings, but it is also the carrier of systems of relevance that are expressed within the language as the named and the unnamed, as mentionable or neglectable. Language carries the meanings of a socio-cultural world, as well as carrying intersubjectively valid typifications that enable the individual to overcome the contingency of the world (Srubar, 1988, p. 243). Language is independent of the finiteness of the individual and it overcomes the transcendences of the individual through the fixation of meaning.

Signs enable human beings to overcome the transcendences of the other's world; they are means of communication within the intersubjective life-world and constitute language as a sign-system that carries objectified meaning beyond the finiteness of human existence and therefore transcends human existence.

I have shown that the everyday life-world is characterized by appresentative relations that are given to the individual from the outset. Within these relations, we perform practical activities and work in the mode of everyday common sense thinking. All these appresentative references, as far as their origin, end, or direction is concerned, belong to a finite province of meaning, to the "reality of everyday life." The crucial argument within Schutz's sign theory is the assumption that appresentative references are a means to overcome experiences of transcendence. In this essay, this has been demonstrated by the 
analysis of appresentative references, specifically marks, indications, and signs. They all help to overcome transcendences which themselves belong to the one sphere which Schutz designates as the "reality of the everyday lifeworld;" as transcendences of my actual Here and Now (of space and time), the other and the other's life-world, they belong to my everyday life-world, and in this way they are grasped by my common sense thinking.

However, there are experiences that transcend the finite province of meaning, the "everyday life-world," which refer to the limits posed by nature and the social world and to other provinces of meaning or "sub-universes" in the terminology of William James, like, for example, the worlds of science, art, religion, myth, and politics as well as the worlds of imagination and dream. At this point within his theory of sign and symbol, Schutz defines a specific form of appresentative reference called symbol, by which human beings are able to apprehend these transcendent phenomena, a process analogous to the apprehension of the world of perception.

\section{The Transcendence of Nature and Society: Its Overcoming by the Symbol}

Within this ideal-typical model of transcendences, Schutz for systematic reasons defines a third stage of the transcendences of the life-world; following the description of the transcendences of the solitary I's life-world and the transcendences of the world of the other, he demonstrates a further level of the transcendences of nature and society and their overcoming by the appresentational relation of the symbol.

Nature transcends my life-world in time, having existed before my birth and continuing to exist after my death, before any creature at all appeared and possibly surviving mankind as such. In space the world within my potential reach transcends the world within my actual reach, but because it belongs to my experience of the infinite horizons of my world within potential reach, every potential reach that is transformed into an actual one will show the same infinity of new horizons. The social world transcends the reality of my everyday life in a similar way: I was born into a pre-organized social structure, thus the social world will also survive me. This world is from the outset shared by fellowmen, who are organized in groups which have their particular open horizons in time, in space, and also in their social distance. My actual social environment always refers to a horizon of potential social environments, in which the existence of an infinity of transcendent social worlds and of posterities are situated (Schutz, 1989a, p. 277). The situational transcendence of the natural and social realms is imposed on me in a double sense; at any moment in my existence I find myself in the midst of a natural and social environment which is part of my biographical situation and is therefore experienced as inescapably belonging to it. 
The order of nature and of society as such is, however, given as identical to all human beings within lived experience. The "givenness" of nature and social order for everyday thinking is an element of our knowledge. This order reveals itself to our analogical apprehending in images; once these images are constituted, they are taken for granted, as are the transcendences to which they refer. In our cultural environment itself we find socially approved systems which offer answers for our quest for the unknowable transcendences. "Means and ways were developed socially to apprehend the disquieting phenomena transcending the world of everyday life in a way analogous to the experience of familiar phenomena within it" (Schutz, 1989a, p. 279). This can be achieved through the creation of appresentational references of a higher order, which Schutz calls symbols in contradistinction to the marks, indications, and signs discussed so far. The symbol serves as an appresentational reference of a higher order in which the appresenting member of the pair is an object, fact, or event within the reality of the everyday life-world, whereas the appresented member of the pair is an idea that transcends our experience of everyday life. ${ }^{14}$

We need to understand these universal forces of nature and the social world and, insofar as we cannot comprehend them, we must evoke and appease them. ${ }^{15}$ Since the individual is unable to do this alone, he or she can achieve it only by working with others; this is a matter for the group and its organization (Schutz, 1989a, p. 281). In this sense, the symbol is an appresentational reference of higher order; Schutz intends at this point to establish symbolic references as those that are relevant in any symbolic situation. The imposed transcendences of nature and society require a mechanism to make the "incomprehensible" understandable for the everyday reality of the individual; the community itself has already found recipes that are stored in form of symbols in our common stock of knowledge.

\section{Multiple Realities and Symbolic Appresentation}

According to William James' definition, several - possibly infinite - orders of reality correlate to modes of consciousness with a respective specific style of existence. Each of these worlds or subuniverses is real in a characteristic way while we concentrate on it; this reality disappears when we no longer pay attention to it. Schutz prefers to designate these realities as "finite provinces of meaning" because he emphasizes the constitution of reality by the meaning of our experience and not by the ontological structure of the objects. Each finite province of meaning has its own particular style of cognition and experience: our paramount world of the real outer objects which we can manipulate operatively by our actions, the worlds of imagination and fantasies, such as the play-world of the child, the world of the insane, but also the world of 
the work of art, the world of dreams or the world of theoretical-scientific contemplation. Exactly this particular cognitive style, and the peculiar set of our experiences, constitutes each of these into a finite province of meaning. Moreover, each of these provinces of meaning is characterized by: (1) a specific tension of consciousness, including the attention à la vie founded on it; (2) a specific epoché; (3) a dominant form of spontaneity; (4) a specific form of self-experience; (5) a specific form of sociality and (6) a specific time-perspective (Schutz, 1989a, p. 283).

Whereas James calls the subuniverse of the sensuously perceptible physical world the "paramount reality," Schutz prefers to take as paramount reality the finite province of meaning called the reality of everyday life. The reason is that we constantly participate in this reality, even during our dreams, by means of our bodies, which are themselves things in the outer world; it is this realm to which we gear our bodily activities, and which we can change thereby.

For a further elaboration of his theory of the sign and of the symbol, Schutz needs to specify symbolic appresentation as a way of including experiencing within these multiple realities as finite provinces of meaning which are all constituents of the life-world. As we have demonstrated, all appresentational references are characterized by a specific transcendence of the appresented object in relation to the actual Here and Now of the interpreter. With the exception of symbolic appresentation, the three parts of the appresentational relation - the appresenting and the appresented member of the pair as well as the interpreter - are located on the same level of reality; they pertain to the paramount reality of everyday life. The symbolic reference, however, is characterized by the fact that it transcends the finite province of meaning of everyday life: the appresenting member of the pair pertains to it, whereas the appresented member has reality in another finite province of meaning. For example, the cross as religious symbol for "salvation" and "eternal life" is an object in the reality of everyday life as well as the interpreter of the symbol. The ideas of "salvation" and "eternal life" belong to the finite province of meaning of "religion," which transcends the everyday life-world.

Schutz defines the symbol as follows: "a symbolic relationship is an appresentational relationship between entities belonging to at least two finite provinces of meaning so that the appresenting symbol is an element of the paramount reality of everyday life" (Schutz, 1989a, p. 285). The transition from the paramount reality to other finite provinces of meaning follows through a leap, the subjective correlate of which, according to Schutz, is a shock experience. The world of everyday life is taken for granted by our common sense thinking, seeming to us to be natural reality. Only a specific shock experience can compel us to break through the limits of this finite province of meaning and to shift the accent to a transcendent one. Such shock experiences are, e.g., the curtain in the theater, contemplation of a framed image, falling asleep, the Kierkegaardian leap into the religious sphere, or a theoretical attitude. Obvi- 
ously, in our daily routine we frequently leap into these different spheres of the life-world: we day-dream in a world of imagination, we play with children, we pray, or we discuss philosophical problems.

The most important characteristic of the symbol is that it represents ideas and their interrelations experienced in other realities within our reality of everyday life. Symbols as objects, facts, or events in our everyday life are the means to communicate our experiences of other transcendent realities because they are present and accessible to everyone within our everyday life-world. Scientific theory or literature, for example, only use the "words" of our everyday life as symbols which appresent realities of these finite provinces of meaning, but their validity or utility is almost completely independent of any reference to the commonsense thinking of everyday life and its realities.

The following example from literary history can serve to illustrate this: Dostoyevsky's realist literature gives an excellent illustration for the functioning of this kind of symbolism. Through his use of everyday language he creates convincing ideal-typical characters, for instance, those depicted in his Brothers Karamazow, which represent other realities to be experienced by the reader on several distinct symbolic levels. The Karamazow family as such is an allegory in the form of a microcosm in which the main problems and inner contradictions of humanity are mirrored. This function becomes apparent in the confrontation between the three brothers and their father: Ivan, the intellectual man, Dmitry, the sensual, aesthetic man, and Aliosha, "the man of god," or spiritual man confront each other and their father, Fjodor Pavlovich, who is portrayed as the "incarnation" of evil. These characters also symbolize the clash of different world views in the Russia of Dostoyevsky's time: the clash between Western intellectual Nihilism, Russian Orthodoxy, and Catholicism. The three brothers also form together the "fragmented hero;" they symbolize the mind, body and soul of one personality, whereas each character for itself - on different personal levels of the fragmented hero - is responsible and guilty for the father's death, even if the lackey Smerdyakov, presumably Fyodor Pavlovich's illegitimate son, is the actual executor of the murder (cf. Dostoyevsky, 1990).

Within the finite province of the meaning of a work of art, the interrelationship of the symbols as such is the essence of its literary content, and it is unnecessary and useless to look for the significance of these symbols with reference to the level of the world of daily life. The connection of the symbols with such objects has been cut off - the use of the appresenting elements is just a means of communication; literature communicates by using ordinary language. The ideas symbolized by this language are real entities within the finite province of poetical or prosaic meaning. Schutz employs Jaspers' definition of the "cipher" in reference to transcendent experiences, defining them as understood by those who possess the existential key. Jaspers' famous statement has to be interpreted in exactly this way: "The symbol establishes com- 
munion without communication" (Jaspers, 1973. pp. 24-25, cf. also Schutz, 1989a, p. 287). The individual is not only able to experience within finite provinces of meaning, but is also able to communicate these experiences to others by the means of symbols because these are manifestations within our everyday life-world. Therefore, the intersubjectivity of the different, transcendent finite provinces of meaning can be established and experiences of these multiple realities can be communicated. Symbolism in this sense is a mechanism which establishes connections between the different reality spheres with the paramount reality of the everyday life-world.

\section{Symbol and Society}

In the last, probably most significant section of his theory of sign and symbol, Schutz extends the conception of the symbol to a further stage. He points out that some realities of the life-world with their specific cognitive styles are socializable, and therefore can be transferred into knowledge and action relationships. They themselves may be institutionalized and, as institutions situated outside the reality of everyday life, can become part of the everyday-transcending order of "society" (Srubar, 1988, p. 246). Examples of such systems of appresentational references are philosophy, religion, science, art, and politics. However, in this case, the relationship of symbolization is reversed: within these systems the reality of everyday life is symbolically appresented.

Ideas symbolized through language that are entities within finite provinces of meaning, such as the reality of everyday life, are "ciphers" or symbols which can only be understood by those who have the existential key to them. These symbols are "dark signs" of transcendent experience: the "darkness of transcendence," as, for example, the distinct world of poetry, is only accessible by the insight of the symbols. Only in this way can symbols establish communion without communication (Jaspers, 1973, p. 25). Ciphers and symbols are metaphysical objects that represent the language of transcendence - Jaspers calls this a "cipher-script" in which it is impossible to separate the symbol from what is being symbolized. Cipher-script brings transcendence into the present, but it cannot be interpreted; the symbol relation would have to be destroyed for an interpretation of the symbol and this is impossible because the transcendence appears to me only in the symbol but is itself not the symbol. Even though the reading of the cipher-script takes place in clear consciousness, doing so is a matter of my "standing" within unconscious symbolism and this symbolism is not additionally known to me qua symbolism (Ibid., p. 141). However, conscious symbolism is the equivalent to having or possessing things in the world with a reference to other existing objects in the sense of sign, metaphor, comparison, representation, model - in this case it is not cipher-script. 
In Schutz's argument, the dependence of the appresentational symbolic relation on the social environment constitutes the basic problem of any genuine sociology of knowledge. In fact, human beings find themselves from the outset in surroundings already mapped out for them by others, i.e., premarked, preindicated, ${ }^{16}$ presigned, and even presymbolized. Therefore, our biographical situation in everyday life is always a historical one because it has been co-constituted by the socio-cultural process that has contributed to the actual configurations of its environment.

Hence, only a small fraction of the stock of knowledge at hand originated in the individual's own experience, whereas the greater part is socially derived and has been handed down to him or her by parents and teachers etc. as social heritage (Schutz, 1989a, p. 288). It consists of a set of systems of relevant typifications of typical solutions for typical practical and theoretical problems, of typical precepts of typical behavior, including the pertinent systems of appresentational references. This knowledge is taken for granted beyond question by the respective social group, and thus accepted as socially approved; this concept comes close to what Max Scheler calls relatively natural worldview (Scheler, 1980, p. 60ff.). For the description of a world taken for granted by a particular society it is entirely irrelevant whether the socially derived and approved knowledge is indeed true knowledge. In the sense of the Thomas-theorem ("If men define situations as real, they are real in their consequences." Thomas, 1970, p. 572), all elements of such knowledge, including appresentational references of any kind, if believed to be true, are real components of the "definition of the situation" by the members of the group. Schutz incorporates this idea in his terminology: "If an appresentational relationship is socially approved, then the appresented object, fact, or event is believed beyond question to be in its typicality an element of the world taken for granted." (Schutz, 1989a, p. 288). A native language, for example, can be taken as a set of references approved by a linguistic community which has predetermined what features of the world are worthy of being expressed and what typifications, conceptualizations, abstractions, generalizations, and idealizations are relevant for achieving typical results by typical means.

\section{Symbolic Appresentation of the Social World}

We have already demonstrated that the face-to-face relationship is the center of the social world; only in the we-relationship of the surrounding world do the partners, by their mutual biographical involvement, experience one another as unique individuals. Schutz argues that we experience the world of commonsense thinking on two levels of appresentational references (Schutz, 1989a, pp. 291-193) that are exactly the first two medium transcendences of the 'world of the other': 
(1) On the first level, we experience individual fellow human beings and their cogitations as realities within the world of everyday life. Through communication, we can apprehend them and their mental experience only analogously by appresentational references; in this sense, the world of the other transcends mine, but this kind of boundary is an "immanent transcendence" still within the reality plane of the everyday life-world - symbolic representation does not take place on this level.

(2) The second level describes social collectivities and institutionalized social relations which are, in contrast, not real entities within the province of meaning of the everyday life world, but constructs of common sense thinking that belong to a different subuniverse. For this reason, we can only apprehend them symbolically; the crucial idea is that the symbols appresenting these entities themselves pertain to the paramount reality of the everyday life-world and motivate our actions in it. Social collectivities are experienced, for example, through the encounter with individuals representing the government such as the President, the Queen, congressmen, government officials, etc.

The we-relation as such transcends, as we have shown above, the existence of either of two partners within the paramount reality, and can only be appresented through symbols. My friend and I are both elements of the reality of everyday life, but our 'friendship' as such surpasses our individual province of meaning of the everyday life-world. The idea of the partnership symbolizes our we-relation in different degrees of intimacy and remoteness: we are lovers, comrades, colleagues etc. (Schutz, 1989a, p. 292). Up to this point, all described social relations can be brought within actual reach of the individual; these 'primary groups' are established on the basis of the faceto-face relationship.

(3) According to Max Weber's definition, when a group is larger and not everyone can be experienced in the face-to-face relationship, a certain specific type of action can be expected from each member of the group (Weber, 1978, pp. 40-43). According to Eric Voegelin, human beings experience the social and political organizations by specific appresentations - every political society is a "cosmion, illuminated with meaning from within by the human beings who continuously create and bear it as the mode and condition of their self-realization" (Voegelin, 1952, p. 27). It is illuminated with meaning through an elaborate symbolism - through rites, myths, and theories - whereas the symbols establish the internal structure of such a cosmion; they define the relations of the members of a political society, as well as the different relations between the communities of this society - they are responsible for the existence of this cosmion as a whole.

In terms of Voegelin's argument the self-illumination of society through symbols is an integral, or rather essential part of social reality, because human beings experience society this way as part of their human existence. On the other hand, he claims that society itself becomes the representative of 
something beyond itself, of a transcending reality. All early empires understood themselves as representatives of a transcendent order, of the order of the cosmos, the universe. The empire is a cosmic analogue and its territory is an analogical representation of the world; the ruler himself represents society because on earth he represents the transcendent power which maintains cosmic order (Ibid., p. 54). In this way, the cosmion in its further function can be seen as the symbolical representative of the cosmos. Obviously, this demonstrates how symbols achieve the overcoming of the third medium transcendences of the "world of the other": social collectivities, as entities outside the everyday life-world that transcend the we-relationship, are symbolically represented as cosmions within the everyday life-world. ${ }^{17}$

Significant for the symbolic appresentation of society is the fact that institutionalized systems outside the everyday reality such as religion or politics must employ elements present in the everyday life-world for their symbolization to make intersubjectivity and communication possible. Therefore, these systems establish an order transcending the paramount reality which is able to influence and motivate the actions of human beings by means of symbols. The transcendent order, for example of politics, becomes itself present and effective in everyday life through symbolic appresentation; representatives of this order are considered to be institutions of a higher degree (Srubar, 1988, p. 246). The crucial point in connection to this is the transfer of the transcendent order of "society" into action through symbolic appresentation. A specific dialectic is recognizable: the appresentation is realized by the execution of the action and in doing so, the transcendent order is being indirectly reproduced at the same time. Srubar describes the "meaning clip function" of appresentational systems which assign the transcendent world to human reality in relating the different reality spheres to the working individual. He states that appresentational systems are the bearers of the reciprocity of perspectives and communication which create the everyday life-world as a paramount reality (Ibid., p. 247; cf. also Endreß, 1999, pp. 342-344). Thus, a connection between the everyday life-world and the transcending realities of the social world and nature, as well as with the multiplicity of realities - the worlds of religion, science, politics, arts, etc. - is established. In this way, the appresentational systems transform the world into a life-world by interspersing it with meaning realized by the acting individual from "inside"; and in doing so, they constitute it as a cultural world (Srubar, 1988, p. 248). This links to Voegelin's idea of the cosmion which describes the symbolic self-interpretation of a society - remarkably, this is achieved from "inside the society itself."

The conception of the life-world, established by the late Schutz, is based on the subjectively centered, intersubjective reality of the life-world. The individual experiences in his or her life-world, as we have demonstrated, within different spheres of transcendence; of special interest now - and this is the 
key consideration of this essay - is that the overcoming of these transcendences by signs and symbols again constitutes the structure of the life-world itself.

Since the major part of the social stock of knowledge with its systems of relevant typifications is socially derived, all appresentational systems are also elements of this stock of knowledge from the outset and are socially approved. Therefore, all appresentational forms - indications, marks, signs, and symbols - are typifications with socially approved references to a "world taken for granted." It reveals itself by acting and working; the stock of knowledge, with its given ways of overcoming the transcendences of the life-world, is acquired through socialization, mainly in face-to-face interactions. As we have shown, Schutz describes the we-relation as the basis of human existence; only on this basis can the acting and working individual discover the world. Therefore, the objectively given life-world, which has always been intersubjective, can only reveal itself through action (Srubar, 1988, p. 269).

The objective structure of the life-world results from the transcendences of nature and society and the already socially interpreted and pre-structured possibilities of overcoming these transcendences. Appresentative symbols, as part of the social stock of knowledge which make transcendent realities understandable and give them meaning, serve the acting subject by interpreting what is beyond the boundaries of its life-world. ${ }^{18}$

\section{Conclusion}

The study of Schutz's "Notebooks" shows the importance of symbolization within his conception of the life-world; it turns out to be the integrative mechanism of a pluralistically structured life-world of human beings. Schutz's intention was to dedicate a specific chapter on symbols in his uncompleted work, the Structures of the Life-World, in order to establish the theory of the symbol as an essential component of his theory of the life-world. The actual completion of Structures of the Life-World II by Thomas Luckmann lacks an explication of the symbol as crucial mechanism for establishing the cohesion of the life-world, as central component of constituting the life-world as entity of multiple reality spheres. The reversal of the relationship of symbolization through which other realities such as politics and religion are able to symbolically appresent the reality of everyday life was not taken into consideration, a systematic link with great relevance for the Schutzian conception of the lifeworld. ${ }^{19}$

On the basis of Jaspers' and Voegelin's analyses it can be demonstrated that a cohesion of a life-world with its multiple reality spheres is established through this kind of reverse symbolization; communions and social collectivities are constituted of ideas and experiences of realities transcendent to the reality of the everyday life-world. ${ }^{20}$ As far as society as such is concerned, the self-illu- 
mination of society through symbols as elements of the everyday life-world is the essential mechanism by which the experience and perception of this society as part of the human existence of the individual is made possible. The dialectic that has been introduced can illustrate this: symbolic appresentation on the basis of the social stock of knowledge, the constitution of a "cosmion" with references to transcendent realities, which is accomplished within human action, simultaneously establishes the order of society through the objectification of this order as a transcendent one. In exactly this way the working individual in his or her everyday life-world is able to experience the "totality" of the life-world with its different reality spheres; the objective "structures of the life-world" are not only posed by nature and society, they also result from the experience of multiple realities and the objectification of appresentational symbols which stand for these realities. In this way, Schutz is able to show how social cosmions are established through symbolic appresentation and how they are integrated within the life-world of the individual.

Signs and symbols are elements that establish "links" or "bridges" between the multiple reality spheres of the life-world of the individual; in this sense they are crucial elements within the process of (self-)structuring of the lifeworld. Alfred Schutz's theory of the sign and the symbol is an essential component of his theory of the life-world; all the different dimensions of the life-world with their transcendences of space, time, sociality, and the multiple reality spheres are integrated by means of signs and symbols. In a specific form of indirect communication, symbols and systems of symbols are able to appresent ideas from everyday transcendent realities, and through reverse symbolization, these symbols are able to constitute societies as cosmions that are subjectively experienced by the individual.

\section{Notes}

1. Already in his early writings concerning his Theory of the Life Forms under the influence of the life-philosopher Henrí Bergson, Schutz developed a theory of symbolization. In his model of the life forms - as ideal types defined levels of the "attitude of the subjective consciousness towards the world" - he connects the different life forms with distinct tensions of consciousness through the mechanism of symbolization. Within this early theory of the symbol, "symbols" are "pictures of meaning" that have the function of connecting the different life forms (cf. Schutz, 1982; Srubar, 1988, pp. 44-131; Wagner, 1977). However, this essay concentrates on Schutz's later theory of the symbol which has a decisive status within his theory of the life-world.

2. In a letter to Schutz, Maurice Natanson describes the essay on symbols as "without any doubt an important contribution to the theory of signs and communication." Cf. Letter Natanson to Schutz, 7/21/1954, Social Science Archive Konstanz.

3. Cf. "Symbol, Reality, and Society" and "On Multiple Realities," In Alfred Schutz (1962) Collected Papers, Vol. 1: The Problem of Social Reality, pp. 287ff, 207ff. The Hague: Martinus Nijhoff. 
4. Cf. Alfred Schutz (1989a). Appendix: "The Notebooks". In Alfred Schutz and Thomas Luckmann, The Structures of the Life-World, Vol. 2, p. 159ff. Evanston/Ill.: Northwestern University Press.

5. The reconstruction of this "symbol chapter" - the way Schutz probably would have written it himself - along the manuscripts of the "Notebooks" was part of the analysis for my masters thesis; cf. Jochen Dreher (1997). Die Entwicklung des Symbolbegriffs im Werk von Alfred Schütz. Die Überwindung der Transzendenzen der Lebenswelt durch Zeichen und Symbole. Konstanz. On Schutz's concept of the sign and the symbol and the communicative order of the life-world, cf. especially the Introduction to the new German Schutz Work-Edition Theorie der Lebenswelt. Die kommunikative Ordnung der Lebenswelt. Werkausgabe, Vol. V.2. (Schütz, 2003) by Hubert Knoblauch, Ronald Kurt, and HansGeorg Soeffner.

6. As an exception Maurice Natanson's Schutz reception about transcendences and multiple realities in Anonymity (Natanson, 1986, pp. 120-144) and Ilja Srubar's Kosmion, which underlines the significance of pragmatically generated systems of sign and symbol or Schutz's life-world as a cultural world, should be mentioned (Srubar, 1988, Ch. V).

7. Here I cite above all the Third Notebook from Seelisberg; cf. Schutz, 1989a, p. 243 in a comparison with the German original III. Notizbuch, Seelisberg; cf. Schütz and Luckmann, Strukturen der Lebenswelt II, p. 306.

8. A distance between Schutz's and Husserl's position of the "understanding of the Other" at this point is obvious. In a letter to Schutz, the phenomenologist Herbert Spiegelberg describes Schutz's view concerning the prerequisites of communication as "too pessimistic," in his opinion Schutz neglects "empathy," in Husserl's sense the basis for intersubjectivity. Cf. Letter Siegelberg to Schutz, 4/11/1954, Social Science Archive Konstanz/ Germany.

9. Schutz's friend Aron Gurwitsch describes the meaning extension of the Husserlian concept of appresentation in a letter (September 10, 1954) with the following words: "You understand appresentation in a much broader and thus more formal manner than Husserl. You understand under the word simply the pairing of elements, one of which is transcendent, on the most various levels of transcendence." (Schutz/Gurwitsch, 1989a, p. 231).

10. In his completion of the Structures of the Life-World, Thomas Luckmann defines them as "medium transcendences," as opposed to the "little transcendences" (of the solitary I) and the "great transcendences" (of nature and society), without differentiating these transcendences of the intersubjective life-world the way Schutz planned it in his "Notebooks." Here we use these concepts because they prove to be suitable for systematic reasons.

11. Schutz describes this situation in using Ortega and Gassets expression of We are growing old together. The two fluxes of inner time, yours and mine, e.g., in considering the event of "We see the flying bird" become synchronous in outer time, and thereby with one another (cf. Ortega and Gasset, 1957, Ch. 3). This is especially important for the investigation of events in the outer world that serve as vehicles for communication, like significant gestures and language.

12. Remarkably, Schutz intended to use Heidegger's concepts of Being-with and Being-withone-another from Being and Time (1962) to elaborate his concept of the we-relation (cf. Schutz, 1989a, p. 265). Heidegger opposes the idea that "solitary" subjects are able to access to the world of the other in Husserl's conception, to access their psychic life through "empathy." An essential element of the Dasein, the Being-in-the-world of humans, is that man finds himself in the world among others, as he was "there too", among others. The "Being-with" determines existentially the Dasein (as its structure), even if the Other is 
in fact not present-at-hand or cannot be perceived. Even the loneliness of the individual is a modality of "Being-with in the world." "This Dasein-with of the Others is disclosed within-the-world for a Dasein, and so too for those who are Daseins with us [die Mitdaseienden], only because Dasein in itself is essentially Being-with." (Heidegger, 1962, p. 156, § 26). In Heidegger's view, the human being has always been "among other human beings," and only on this basis can isolated subjects be split off as individuals. The cognizant, experiencing subject is then itself an epistemological construct. Schutz's perspective, which grasps the we-relation and intersubjectivity as life-worldly phenomena and in which intersubjectivity is the ontological basic category of human existence, comes quite close to Heidegger's position. Presumably, Heidegger's ideas influenced the Schutzian conception with its significance of the we-relation.

13. As distinct from Husserl's theory of intersubjectivity, Schutz demonstrates that intersubjectivity as a life-world phenomenon is a constituent of human existence: "It is the fundamental ontological category of human existence in the world and therefore of all philosophical anthropology. As long as man is born of women, intersubjectivity and the we-relationship will be the foundation for all other categories of human existence. The possibility of reflection on the self, discovery of the ego, capacity for performing any epoché and the possibility of performing of all communication and of establishing a communicative surrounding world as well, are founded on the primal experience of the werelationship." (Schutz, 1970, p. 82).

14. This definition of the symbol corresponds with Karl Jaspers' concept of the symbol who defines it as the objectification of the nonobjective in itself, of an idea. In this sense the symbol only can be interpreted through other symbols and is responsible for "meaning outside the world" (Jaspers, 1973, pp. 15-16).

15. Within mythical experience, the relationship between human being, society and naturewithin the society of life - is such that any element in any of these orders may become a symbol, appresentationally referring to corresponding elements in any of the other orders (Cassirer, 1972, p. 83). The crucial point is the existence of a structural unity between the microcosm "man" and the macrocosm "universe" that is produced by the structure of society and based on a fundamental principle; e.g., the confrontation of master and servant within the hierarchy of society can be derived from the cosmic order. Furthermore, the cosmos, the individual and the social community form a unity and they are all in the same way subject to universal forces that govern all events. There is, for example, an appresentative relationship between the order of society with its hierarchies of sovereigns and subordinates, and the order of celestial bodies.

16. Schutz discussed only the concepts of "marks" and "indications" in relation to the supposedly solitary I's life-world for the sake of a clearer presentation to map out the world within the solitary individuals' reach (Schutz, 1989a, p. 287).

17. Schutz's division of the "transcendences of the world of the other" into three spheres was elaborated by Hans-Georg Soeffner as a part of his research on symbolism with a stronger emphasis on interaction in concentrating exclusively on the social world. In his definition, the human being is a sign-using and interpreting creature which develops its ability to use signs in concrete situations with concrete interaction partners. Soeffner adopts Schutz's conception of the medium transcendences and refines the Schutzian concepts into the following terminology of the three spheres of social action and knowledge: (1) The face-to-face-relationship of mutual perception and control which enables the acquisition of abilities and routines of interpretation within socialization; (2) The world in "potential reach" as the world of social action in indirect mode which characterizes the sector of institutionally imparted social action; (3) The realm of symbolically imparted knowledge and action. The symbolically shaped cosmos of world views with its stored 
traditions can be reached by face-to-face-interaction and can also influence it, however it is not reachable from this "work-zone" (Soeffner, 1990, 1991, p. 67).

18. Here we can recognize the difference from Husserl's conception, in which signs and symbols that structure the reality are only contents of consciousness of the solitary I; Husserl describes appresentation as a mere performance of consciousness, whereas Schutz also claims the pragmatic part of the function of signs and symbols. For Schutz, perception is a life-worldly phenomenon, in contrast to Husserl; Schutz already takes the appresentative structures that lead to the constitution of the life-world for granted.

19. However, the interdependence of "symbolic universes" with subjective reality was focused in Berger and Luckmann's (1987, p. 95ff) The Social Construction of Reality. They describe how symbolic universes provide order for the subjective apprehension of biographical experience.

20. One significant distinction can be discovered in Luckmann's completion of the Structures: whereas Schutz argues that the first and originate experience of the "transcendence of the world" for every human existence within the life-world is certainly death, Luckmann considers death to be the boundary of the life-world, which can only be overcome without returning to the life-world. Schutz's reflections were definitely influenced by Jaspers' and Heidegger's positions; the original experience of the transcendence of death does not need "pairing" or "passive synthesis" and no appresentational references, as Schutz argues in a controversy with Charles Morris (Schutz, 1989, pp. 125-127). This point of view resembles Heidegger's concept of "Being-towards-death", whereas fear of death constitutes the fundamental anxiety of human existence. In Luckmann's view, death is not a life-worldly experience, equivalent to the experience of other transcendences. One certainly knows about one's own death, but this knowledge does not refer to a personal experience. Luckmann argues, as opposed to Schutz's position, that within deep life crisis the "fundamental anxiety" is not suspended because of the knowledge of the own death; exactly this anxiety motivates the way in which humans cope with crisis. According to Schutz's argument, death is the most original experience of transcendence - he differentiates it from other experiences of transcendence - which in fact belongs to the life-world, and in this sense, the experience of death is an element of the situation of human existence in the world.

\section{References}

Berger, P.L. and Luckmann, T. (1967). The Social Construction of Reality: A Treatise in the Sociology of Consciousness. Garden City, New York: Doubleday.

Cassirer, E. (1972). An Essay on Man. An Introduction to a Philosophy of Human Culture. New Haven, London: Yale University Press.

Dostoyevsky, F. (1990). The Brothers Karamazov. A Novel in Four Parts with Epilogue. Trans. and annotated by Richard Pevear and Larissa Volokhonsky. London: Quartet.

Dreher, J. (1997). Die Entwicklung des Symbolbegriffs im Werk von Alfred Schütz. "Die Überwindung der Transzendenzen der Lebenswelt durch Zeichen und Symbole. "Published online: http://www.ub.uni-konstanz.de/kops/volltexte/1999/109.

Endreß, M. (1999). Alfred Schütz, (1899-1959). In D. Käsler (Ed.), Klassiker der Soziologie, Bd. 1. Von Auguste Comte bis Norbert Elias, pp. 334-352. München: Beck.

Heidegger, M. (1962). Being and Time. New York, Evanston: Harper \& Row.

Husserl, E. (1954). Die Krisis der europäischen Wissenschaften und die transzendentale Phänomenologie. Eine Einführung in die phänomenologische Philosophie. Husserliana $B d$. VI. Den Haag: Nijhoff. 
Husserl, E. (1985). Erfahrung und Urteil. Untersuchungen zur Genealogie der Logik. Hamburg: Meiner.

Husserl, E. (1987). Cartesianische Meditationen. Eine Einführung in die Phänomenologie. Hamburg: Meiner.

James, W. (1950). The Principles of Psychology, Vols. I-II. New York: Henry Holt.

Jaspers, K. (1973). Philosophie III. Metaphysik. Berlin, Heidelberg, New York: Springer.

Knoblauch, H. (1995). Kommunikationskultur. Die kommunikative Konstruktion sozialer Kontexte. Berlin, New York: De Gruyter.

Luckmann, T. (Ed.) (1983). On the Boundaries of the Social World. In Life-World and Social Realities, pp. 42-67. London: Heinemann.

Natanson, M. (1986). Anonymity. A Study in the Philosophy of Alfred Schutz. Bloomington: Indiana University Press.

Ortega y Gasset, J. (1957). Man and People. New York: Norton \& Company.

Scheler, M. (1980). Die Wissensformen und die Gesellschaft. Probleme einer Soziologie des Wissens. Bern, München: Franke.

Schutz, A. (1962). Collected Papers, Vol. I. The Problem of Social Reality. The Hague: Martinus Nijhoff.

Schutz, A. (1970). Collected Papers, Vol. III. Studies in Phenomenological Philosophy. The Hague: Martinus Nijhoff.

Schutz, A. (1982). Life Forms and Meaning Structure. London: Routledge \& Kegan Paul.

Schutz, A. (1989a). Appendix: The Notebooks. In A. Schutz and T. Luckmann, The Structures of the Life-World, Vol. 2, pp. 159-324. Evanston: Northwestern University Press.

Schütz, A. (2003). In H. Knoblauch, R. Kurt and H.-G. Soeffner (Eds.), Theorie der Lebenswelt. Die kommunikative Ordnung der Lebenswelt. Werkausgabe, Bd. V. 2. Konstanz: UVK (in print).

Schutz, A. and Gurwitsch, A. (1989). In R. Grathoff (Ed.), Philosophers in Exile. The Correspondence of Alfred Schutz and Aron Gurwitsch, 1939-1959. Bloomington and Indianapolis: Indiana University Press.

Schutz, A. and Luckmann, T. (1974). The Structures of the Life-World, Vol. 1. London: Heinemann.

Schutz, A. and Luckmann, T. (1989). The Structures of the Life-World, Vol. 2. Evanston: Northwestern University Press.

Schütz, A. and Luckmann, T. (1994). Strukturen der Lebenswelt II. Frankfurt a. M.: Suhrkamp.

Soeffner, H.-G. (1990). Appräsentation und Repräsentation. Von der Wahrnehmung zur gesellschaftlichen Darstellung des Wahrzunehmenden. In H. Ragotzky and H. Wenzel (Eds.), Höfische Repräsentation. Das Zeremoniell und die Zeichen, pp. 43-63. Tübingen: Niemeyer.

Soeffner, H.-G. (1991). Zur Soziologie des Symbols und des Rituals. In J. Oelkers and K. Wegenast (Eds.), Das Symbol-Brücke des Verstehens, pp. 63-81. Stuttgart: Kohlhammer.

Srubar, I. (1988). Kosmion. Die Genese der pragmatischen Lebenswelttheorie von Alfred Schütz und ihr anthropologischer Hintergrund. Frankfurt a. M.: Suhrkamp.

Thomas, W.I. (1970). The Child in America. Behavior Problems and Programs. New York: Johnson Repr.

Voegelin, E. (1952). The New Science of Politics. An Introduction. Chicago: The University of Chicago Press.

Wagner, H.R. (1977/78). The Bergsonian Period of Alfred Schutz. Philosophy and Phenomenological Research 38: 187-199.

Weber, M. (1978). Economy and Society: An Outline of Interpretive Sociology. Trans. G. Roth. Berkeley: University of California Press. 